\title{
DETERMINATION OF INFLUENTIAL FACTORS DURING ENZYMATIC EXTRACTION OF GINGER OIL USING IMMOBILE ISOLATED COW RUMEN ENZYMES
}

\author{
Dwi Handayani ${ }^{1}$, Rizka Amalia ${ }^{1 *}$, M. Endy Yulianto ${ }^{1}$, Indah Hartati ${ }^{2}$, Murni $^{3}$ \\ ${ }^{1}$ Department of Chemical Engineering, Faculty of Engineering, Universitas Diponegoro, Kampus \\ Undip Tembalang, Semarang 50239, Indonesia \\ ${ }^{2}$ Department of Chemical Engineering, Faculty of Engineering, Universitas Wahid Hasyim, \\ Sampangan, Gajahmungkur, Semarang 50232, Indonesia \\ ${ }^{3}$ Department of Mechanical Engineering, Faculty of Engineering, Universitas Diponegoro, Kampus \\ Undip Tembalang, Semarang 50239, Indonesia
}

(Received: July 2017 / Revised: February 2018 / Accepted: March 2018)

\begin{abstract}
With respect to its multiple uses, such as in cosmetics, foods, aromatherapy and the pharmaceutical industry, ginger oil has a high value in the world market. The ginger oil obtained from conventional extraction usually has low zingiberene content, possibly due to thermal degradation. To overcome this problem, an alternative ginger oil production process by enzymatic extraction using cow rumen enzymes is investigated. The aim of the research is to obtain the optimum conditions for zingiberene-rich ginger oil extraction by using immobile isolated cow rumen enzyme. The experiments were conducted under varying temperatures (40$60^{\circ} \mathrm{C}$ ), enzyme-substrate ratios $(0.05-0.2)$ and extraction times (1-5 days). The microwave assisted distillation was conducted for 90 minute to separate the ginger oil from its mixture. The zingiberene content in the oil was measured by GC analysis. The most influential factor in the enzymatic extraction of ginger oil was determined by experimental design 23. Analysis of the results shows that for the extraction with a rumen ratio of $1: 5$ at $60^{\circ} \mathrm{C}$, the most influential factor was the extraction time, in this case 5 days, and ginger oil was obtained with zingiberene contents of $21.56 \%$ and $26.28 \%$ at $\mathrm{pH} 5$ and $\mathrm{pH} 4$ respectively. Prolonging the extraction time to 6 days with pH 5 caused a decrease in zingiberene content to $20.76 \%$.
\end{abstract}

Keywords: Cow rumen; Extraction; Ginger pulp; Zingiberene

\section{INTRODUCTION}

Ginger oil is known to have multiple uses, such as in the food, aromatherapy, cosmetics and pharmaceutical industries, meaning that this natural product is an important commodity in the world market. Unfortunately, ginger oil is produced in Indonesia by the steam distillation process and therefore contains low levels of zingiberene compared to camphene and curcumene. Typically, the oil has a positive optical rotation value. In contrast, the commercial standard of ginger oil demands a negative optical rotation value, indicating higher zingiberene content than that of curcumene and camphene. The optical rotation value represents the purity of the ginger oil. The zingiberene content was studied by Koroch (2007), who showed that Madagascan ginger oil has a positive rotation value, and contains relatively small amounts of zingiberene, camphene and curcumene.

\footnotetext{
*Corresponding author's email: riz.chemicalia@gmail.com, Tel: +62-85641377920, Fax: +62-24-7471-379 Permalink/DOI: https://doi.org/10.14716/ijtech.v9i3.489
} 
The low zingiberene content in ginger oil obtained from the conventional distillation process is usually associated with thermal degradation, as zingiberene is a thermolabile compound (Agarwal, 2001). The conventional distillation process takes between 10-18 hours to produce ginger oil, a process which increases the risk of the thermal degradation of zingiberene. Along with the length of time required for the distillation process, the required energy for heating is also higher, so the process becomes less economical. Other ginger oil extraction processes are generally conducted using ethanol, isopropyl alcohol and petroleum ether as solvents. However, process efficiency is relatively low because it may reach the natural limit (phase equilibrium), so the process rate cannot be further increased (Hu et al., 2011). Although the supercritical fluid extraction method can increase the yield of ginger oil, production costs and the price of its specific equipment are extremely high (Mesomo et al., 2013).

To overcome these problems, alternative developments of the appropriate ginger oil production processes need to be established. Considering that zingiberene is a thermolabile compound, the proposed process should be able to extract ginger oil quickly in order to minimize the use of energy, and with controllable temperatures to prevent thermal degradation. Enzymatic extraction techniques are believed to have many advantages over conventional extraction, such as high yields, high selectivity, and being environmentally friendly (Avilla et al., 2005; Panouile et al., 2007; Ptichkina et al., 2008; Paramita et al., 2015). Although there are several patents for enzymatic extraction processes (US Patents No. $5,952,023$, US Patents No. 7,026,152), process efficiency is still less than $80 \%$. This is because about $15-20 \%$ of the total production cost is used for the provision of enzymes. The enzymatic extraction technique is a prospective technology because it can shift the phase equilibrium by degrading the cell wall structure of the plant so that the solute can be extracted properly (Panouile \& Durant, 2007). The technology is suitable for the collection of thermolabile compounds because it has better temperature control than conventional heating processes (Venkatesh \& Raghavan, 2004). Nevertheless, how the application of enzymatic extraction using immobile isolate can increase the yield and zingiberene content in oil production from ginger rhizomes needs to studied. Moreover, Rosenthal et al. (1996) state that in the enzymatic process, the enzyme essentially hydrolyzes the polysaccharide structure, which builds cell walls from seeds and contains oil or proteins that form cells and lipid body membranes.

The fundamental weakness of the enzyme-assisted process approach is that commercial enzymes are relatively expensive and can only be used once (Klein-Marcuschamer et al., 2012). Therefore, to reduce the cost of production when using enzymatic processes, enzymes derived from cow rumen fluid have been isolated and used as the agent (Baba et al., 2013; Li et al., 2017). The isolated enzymes from cow rumen have many advantages over commercial enzymes; for example, they are more stable at high temperatures, have higher specific activity, higher optimum $\mathrm{pH}$, and lower production costs (Heim, 2011). Moreover, in order to use enzymes repeatedly and continuously, they are immobilized in a carrier, such as alginate. The introduction of immobilized enzymes has, in some cases, greatly improved both the technical performance of the industrial processes and their economical aspects (Brena \& Batista-Viera, 2006).

Considering the advantages of cow rumen fluid enzyme and the advantages of enzyme immobilization, this research investigates the possibility of the utilization of immobilized cow rumen fluid enzyme in the ginger oil extraction process. The aim of the research is to obtain the optimum conditions for zingiberene-rich ginger oil extraction by using immobile isolated cow rumen enzyme. The experiments were conducted under varying temperatures $\left(40-60^{\circ} \mathrm{C}\right)$, enzyme-substrate ratios $(0.05-0.2)$ and extraction times (1-5 days). 


\section{METHODOLOGY}

\subsection{Materials}

The raw materials used to produce ginger oil by the enzymatic extraction process were the pulp of red ginger rhizomes, cow rumen and alginate.

Table 1 Ginger oil specification

\begin{tabular}{lcc}
\hline \multicolumn{1}{c}{ Characteristic } & $\begin{array}{c}\text { Ginger oil } \\
\text { (ISO 7355) }\end{array}$ & $\begin{array}{c}\text { Ginger oil extracted in } \\
\text { experiment }\end{array}$ \\
\hline Density & $0.870-0.890$ & 0.885 \\
Refractive index & $1.480-1.490$ & 1.50 \\
Optical rotation & $(-20)-(-45)^{\circ}$ & $-15^{\circ}$ \\
Solubility in alcohol 90\% & $1: 4$ & $1: 6$ \\
\hline
\end{tabular}

Chemical reagents for product analysis, such as phosphate buffer, ethanol, distilled water, sodium hydroxide, hydrochloric acid and phenolphtalein indicator, were purchased from Merc, an authorized chemicals distributor in Semarang-Indonesia.

\subsection{Procedure}

The main equipment used in the research was an enzymatic extractor, as shown in Figure 1.

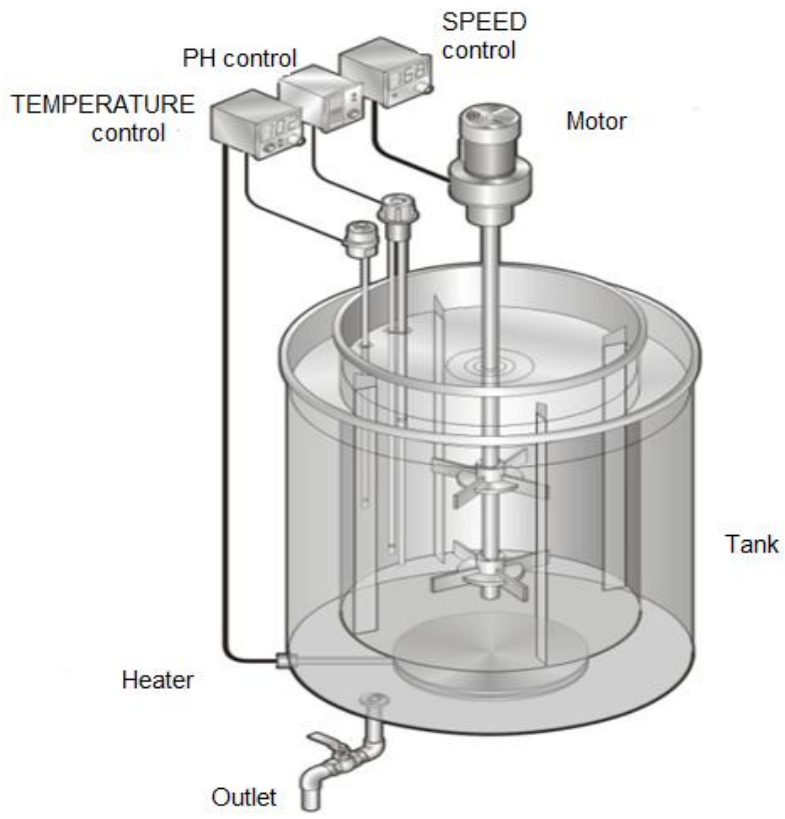

Figure 1 Enzymatic extractor

The operating variables during the study consisted of control variables and independent variables. The experimental research design is shown on Table 2.

\subsubsection{Control variables}

The control variables consisted of: (i) weight of wet ginger pulp: 400 gr (water content: $73.6 \%$ ), giving 105.6 gr of dry ginger pulp; (ii) stirring speed of $60 \mathrm{rpm}$; (iii) water volume of $1000 \mathrm{ml}$; (iv) $\mathrm{pH}$ of 4 and 5; (v) microwave assisted extraction of 150 minutes at $100^{\circ} \mathrm{C}$. 


\subsubsection{Independent variables}

A : Ratio of enzyme:material (\% w/w) 1:20 (-) \& 1:5 (+)

B : Temperature extraction $\left({ }^{\circ} \mathrm{C}\right): 40(-) \& 60(+)$

$\mathrm{C}:$ Extraction time (days): $1(-) \& 5(+)$

Table 2 Experimental research design

\begin{tabular}{cccc}
\hline \multirow{2}{*}{ Run } & $\begin{array}{c}\text { A } \\
\text { Ratio }\end{array}$ & $\begin{array}{c}\mathrm{B} \\
\text { Temperature }{ }^{\circ} \mathrm{C}\end{array}$ & $\begin{array}{c}\mathrm{C} \\
\text { Time (days) }\end{array}$ \\
\hline 1 & 0.20 & 60 & 5 \\
2 & 0.20 & 60 & 1 \\
3 & 0.20 & 40 & 5 \\
4 & 0.05 & 60 & 5 \\
5 & 0.20 & 40 & 1 \\
6 & 0.05 & 40 & 5 \\
7 & 0.05 & 60 & 1 \\
8 & 0.05 & 40 & 1 \\
\hline
\end{tabular}

\subsubsection{Enzymatic extraction procedure}

The extraction was carried out in an enzymatic extractor (Figure 1) with water as the solvent. Enzymes were added to the ginger pulp of ginger at a certain weight ratio. Distilled water was then added and the $\mathrm{pH}$ of the solution was adjusted to the desired value using a phosphate buffer solution. $\mathrm{pH}$ affected the enzyme activity as a biocatalisator to shift the equilibrium phase and increase the production rate because of its ability to degrade the cellulose wall of the oil cells. The extraction process was carried out at certain temperatures and periods of time. Before the feed and solvent were introduced into the extractor, it was conditioned set at the desired temperature. The enzymatic extraction was performed according to the targeted time, and the mixture was distilled with microwaves at $100^{\circ} \mathrm{C}$ for 150 minutes. The ginger oil obtained was measured in volume and the zingiberene content analyzed using GC.

\subsubsection{Data interpretation}

The research was conducted by experiment and data processing with experimental design $2^{3}$ to obtain useful data in determining the most influential parameters in the production process. Experimental design is one way that is often used compared to other conventional approaches, because it has several advantages, namely: (i) it requires fewer experiments to establish the effects of all the variables; (ii) optimum conditions are obtained more precisely because it includes the interaction factors; and (iii) the conclusion is more certain because it is supported by simple statistical calculation methods.

\section{RESULTS AND DISCUSSION}

The experiment research was designed and analyzed using an experimental design system, which means a set of experiments was designed to obtain concrete data to prove the hypothesis. In the experimental design, each of the tested variables was determined at several values; in this study with two values for the independent variables. These independent variables were then combined. The combination of independent variables allows data to be obtained which will help reach the conclusions by using statistical methods. 
Table 3 Zingiberene content of the enzymatic extraction process

\begin{tabular}{cccccc}
\hline \multirow{2}{*}{ Run } & A & B & C & \multicolumn{2}{c}{ Zingiberene Content (\%) } \\
\cline { 5 - 6 } & Ratio & Temperature ${ }^{\circ} \mathrm{C}$ & Time (days) & $\mathrm{pH} \mathrm{4}$ & $\mathrm{pH} \mathrm{5}$ \\
\hline 1 & 0.20 & 60 & 5 & 26.28 & 21.56 \\
2 & 0.20 & 60 & 1 & 18.73 & 10.41 \\
3 & 0.20 & 40 & 5 & 22.51 & 19.48 \\
4 & 0.05 & 60 & 5 & 21.59 & 18.76 \\
5 & 0.20 & 40 & 1 & 19.13 & 9.18 \\
6 & 0.05 & 40 & 5 & 20.15 & 12.75 \\
7 & 0.05 & 60 & 1 & 15.67 & 15.99 \\
8 & 0.05 & 40 & 1 & 7.03 & 6.71 \\
\hline
\end{tabular}

The estimated effect value and the probability value of the experiments conducted at $\mathrm{pH} 4$ are shown in Table 4 and Figure 2.

Table 4 Experimental research analysis at $\mathrm{pH} 4$

\begin{tabular}{ccccccccc}
\hline \multirow{2}{*}{ Run } & \multicolumn{9}{c}{ Factor Code } & \begin{tabular}{c} 
Zingiberene \\
Content \\
\cline { 2 - 6 }
\end{tabular} & $\begin{array}{c}\mathrm{A} \\
\left(\mathrm{I}_{1}\right)\end{array}$ & $\begin{array}{c}\mathrm{B} \\
\left(\mathrm{I}_{2}\right)\end{array}$ & $\begin{array}{c}\mathrm{C} \\
\left(\mathrm{I}_{3}\right)\end{array}$ & Divider & Effect & Result & $\mathrm{P}=\left|(\boldsymbol{i}-\mathbf{0 . 5}) \boldsymbol{x} \frac{\mathbf{1 0 0}}{\mathbf{7}}\right|$ \\
\hline 1 & + & + & + & 26.28 & 8 & Average & 18.88625 & \\
2 & + & + & - & 18.73 & 4 & $\mathrm{I}_{1}$ & -4.0225 & 64.607 \\
3 & + & - & + & 22.51 & 4 & $\mathrm{I}_{2}$ & -4.3725 & 69.607 \\
4 & - & + & + & 21.59 & 4 & $\mathrm{I}_{12}$ & -0.7575 & 17.964 \\
5 & + & - & - & 19.13 & 4 & $\mathrm{I}_{3}$ & -6.7825 & 104.036 \\
6 & - & - & + & 20.15 & 4 & $\mathrm{I}_{13}$ & 0.2125 & 4.107 \\
7 & - & + & - & 15.67 & 4 & $\mathrm{I}_{23}$ & -3.9175 & 63.107 \\
8 & - & - & - & 7.03 & 4 & $\mathrm{I}_{123}$ & -4.0725 & 65.321 \\
\hline
\end{tabular}

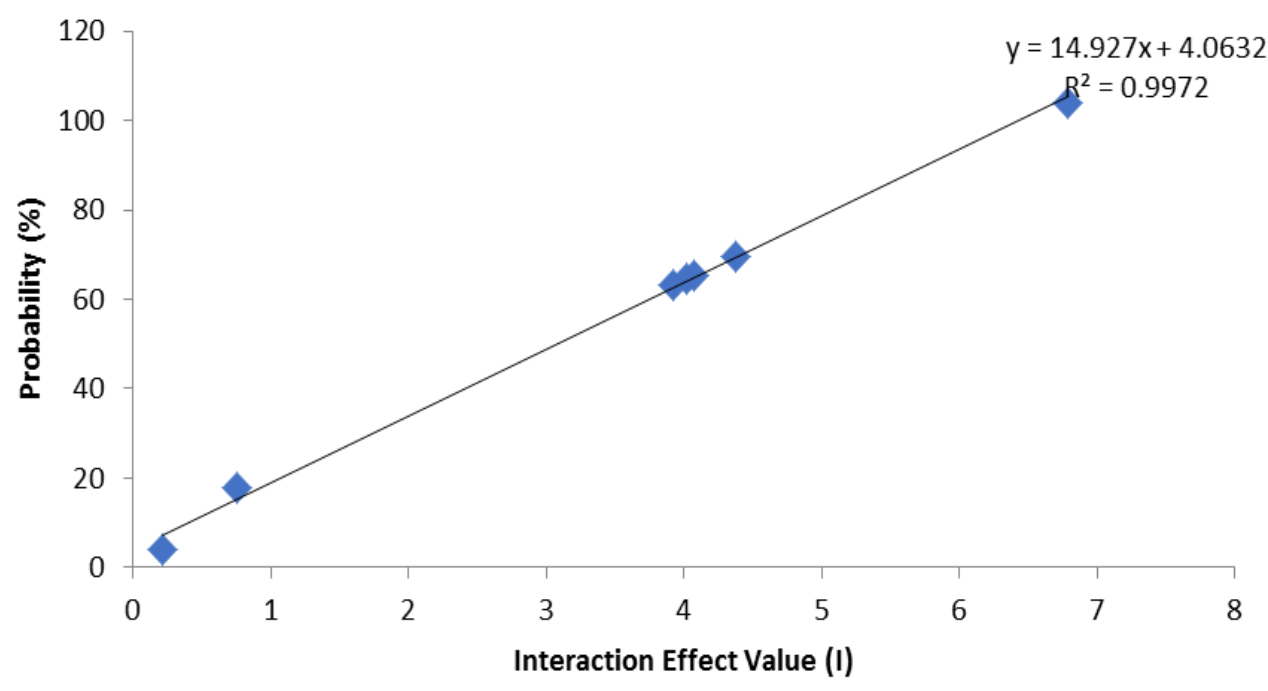

Figure 2 Interaction effect value in experimental research at $\mathrm{pH} 4$

Figure 2 shows that the interaction effect according to equation $\mathrm{Y}=14.927 \mathrm{X}+4.0632$ with $\mathrm{R}^{2}=0.9972$, and that the most influential factor is the extraction time.

The estimated effect value and the probability value of the experiments conducted at $\mathrm{pH} 5$ are shown on Table 5 and Figure 3. 
Table 5 Experimental research analysis at $\mathrm{pH} 5$

\begin{tabular}{|c|c|c|c|c|c|c|c|}
\hline \multirow[b]{2}{*}{ Run } & \multicolumn{3}{|c|}{ Factor Code } & \multirow{2}{*}{$\begin{array}{c}\text { Zingiberene } \\
\text { Content } \\
(\%)\end{array}$} & \multirow[b]{2}{*}{ Effect } & \multirow[b]{2}{*}{ Result } & \multirow{2}{*}{$\mathrm{P}=\mid(i-0.5) \times \frac{100}{7}$} \\
\hline & $\begin{array}{c}\mathrm{A} \\
\left(\mathrm{I}_{1}\right) \\
\end{array}$ & $\begin{array}{l}\mathrm{B} \\
\left(\mathrm{I}_{2}\right) \\
\end{array}$ & $\begin{array}{c}\mathrm{C} \\
\left(\mathrm{I}_{3}\right)\end{array}$ & & & & \\
\hline 1 & + & + & + & 21.56 & Average & 14.355 & \\
\hline 2 & + & + & - & 10.41 & $\mathrm{I}_{1}$ & -4.395 & 69.929 \\
\hline 3 & + & - & + & 19.48 & $\mathrm{I}_{2}$ & 1.760 & 18.000 \\
\hline 4 & - & + & + & 18.76 & $\mathrm{I}_{12}$ & -0.605 & 15.786 \\
\hline 5 & + & - & - & 9.18 & $\mathrm{I}_{3}$ & -6.395 & 98.500 \\
\hline 6 & - & - & + & 12.75 & $\mathrm{I}_{13}$ & 1.540 & 14.857 \\
\hline 7 & - & + & - & 15.99 & $\mathrm{I}_{23}$ & -1.375 & 26.786 \\
\hline 8 & - & - & - & 6.71 & $\mathrm{I}_{123}$ & -5.820 & 90.286 \\
\hline
\end{tabular}

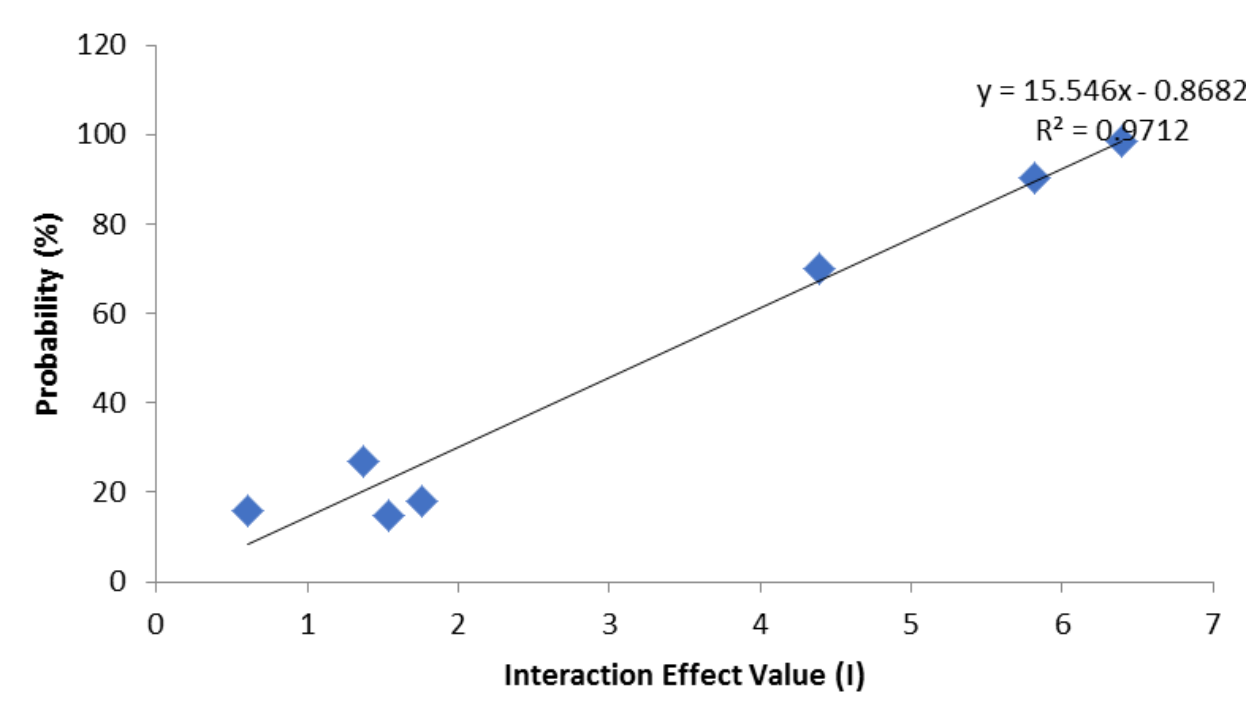

Figure 3 Interaction effect value in experimental research at $\mathrm{pH} 5$

Figure 3 shows that the interaction effect according to equation $\mathrm{Y}=15.546 \mathrm{X}-0.8682$ with $\mathrm{R}^{2}=0.9712$, and that the most influential factor is the extraction time.

Figures 2 and 3 show that the regression of the determination of the influencing process variables was appropriate; it is shown that the value of $\mathrm{R}^{2}$ approaches 1 .

\section{DISCUSSION}

In this research factorial design at two levels was used in the investigation of the enzymatic extraction of ginger oil. In this design, several levels or variations for each variable were selected and the experiment was conducted carefully with all possible variable combinations. From the results, regression analysis was conducted to on the values of the interaction effects and the percentages of probability using the Matlab ${ }^{\mathrm{R}}$ program, so that the influences of the variables on the ginger oil extraction process could be determined. Table 3 shows the results of the zingiberene content of the ginger oil extracts. The estimated effect values and the probability values of the experiments conducted at $\mathrm{pH} 4$ and 5 are shown in Tables 4 and 5, and in Figures 2 and 3.

Figure 2 shows the interaction effect of enzymatic extraction conducted at $\mathrm{pH} 4$. The research shows that the interaction effect according to equation $\mathrm{Y}=14.927 \mathrm{X}+4.0632$, with $\mathrm{R}^{2}=0.9972$. The extraction time was also found to be the most influential factor. In the extraction with a rumen ratio of 0.20 at $60^{\circ} \mathrm{C}$ for 5 days, ginger oil was obtained with a 
zingiberene content of $26.28 \%$. Both sets of experiments showed that the factor affecting enzymatic extraction was time, which was optimum at 5 days. Extraction for 6 days resulted in a ginger oil with a lower zingiberene content of $20.76 \%$ (Table 3 ).

Figure 3 shows that the interaction effect according to equation $\mathrm{Y}=15.546 \mathrm{X}-0.8682$ with $\mathrm{R}^{2}=0.9712$, and that the most influential factor is the extraction time. A rumen ratio of 0.20 , extraction temperature of $60^{\circ} \mathrm{C}$ and extraction period of 5 days gave a ginger oil with a zingiberene content of $21.97 \%$. The research shows that an extraction time of 5 days was the optimum time for the enzymatic extraction, since the zingiberene level decreased when the extraction was conducted for longer. The zingiberene level of the ginger oil was $20.73 \%$ when the enzymatic extraction was conducted for 6 days.

The results show that time was the main influencing factor in the enzymatic process. This type of process for extracting oil is considered to be environmentally friendly (Mariano et al., 2009). It has also been found that particle size, water content, time, and the weight ratio of enzyme substrates affect the enzymatic process. Moreover, Rosenthal et al. (1996) report that in this process, the enzyme essentially hydrolyzes the polysacharide structure, which builds cell walls from the seeds and contains oil or proteins that form cells and lipid body membranes. The zingiberene content obtained by this enzymatic process has been found to be higher than from other methods, such as soxhlet extraction. The basis of the enzymatic process is to hydrolyze the polysaccharide structure which builds the ginger oil cell walls. The penetration of cow rumen enzymes causes damage to the polysaccharide structure, hence the ginger oil in its pouch can be extracted. This is due to the move from the oil phase to the aquatic phase. At the same temperature and time, this causes more diluents to cross over into the aquatic phase. Nour et al. (2017) extracted ginger oil by supercritical fluids and soxhlet extraction. They found that the zingiberene content of the ginger oil extracted by the soxhlet (solvent semi-continuous extraction) method for 6 hours with n-hexane was only $13.74 \%$, while supercritical fluid extraction was able to produce ginger oil extract with a zingiberene content as high as $16.98 \%$.

\section{CONCLUSION}

Evaluation of the effect of the process parameters (temperature, enzyme-substrate ratio and extraction time) on the enzymatic extraction using rumen immobilized enzyme isolates on ginger oil production from ginger pulp has been conducted and it is concluded that extraction time is the most influential factor. At $\mathrm{pH} 4$ and $\mathrm{pH} \mathrm{5}$, optimum conditions were achieved when the rumen enzyme was used at a ratio of $1: 5$ at $60^{\circ} \mathrm{C}$ and with a 5 hour extraction time. The ginger oils obtained had zingiberene contents of $21.56 \%$ and $26.28 \%$ for $\mathrm{pH} 4$ and 5 respectively. Extraction for a longer period resulted in a reduction in the zingiberene content.

\section{ACKNOWLEDGMENT}

The authors would like to thank the LPPM of Universitas Diponegoro for financial support through Riset Pengembangan dan Penerapan 2017 under contract No. 275107/UN7.5.1/PG/2017.

\section{REFERENCES}

Agarwal, M., Walia, S., Dhingra, S., Khambay, B.P., 2001. Insect Growth Inhibition, Antifeedant and Antifungal Activity of Compounds Isolated/derived from Zingiberofficinale Roscoe (Ginger) Rhizomes. Pest Management Science, Volume 57(3), pp. 289-300 
Avraham, R., Keneth, J.P., 1994. Method for Treatment of Cancer by Oral Administration of Modified Pectin. US Patents No. 7,026,152

Baba, Y., Tada, C., Fukuda, Y., Nakai, Y., 2013. Improvement of Methane Production from Waste Paper by Pretreatment with Rumen Fluid. Bioresource Technology, Volume 128, pp. 94-99

Brena, B.M., Batista-Viera, F., 2006. Immobilization of Enzymes: A Literature Survey. Immobilization of Enzyms and Cells, $2^{\text {nd }}$ Edition, pp. 15-30, Humana Press Inc., New York

Dominguez, H., Nunez, M.J., Lema, J.M., 1994. Enzymatic Pre-treatment to Enhance Oil Extraction from Fruits and Oilseeds: A Review. Food Chemistry, Volume 49(3), pp. 271-286

Guenther, E., 1952. The Essential Oils Volume VI. D. Van Nostrand Company Inc., New York

Heim, S., 2011. Technology Offer New Cellulase from Cow Rumen. Foundation for Promotion of Life Science

Hu, J., Guo, Z., Glasius, M., Kristensen, K., Xiao, L., Xu, X., 2011. Pressurized Liquid Extraction of Ginger (Zingiber officinale Roscoe) with Bioethanol: An Efficient and Sustainable Approach. Journal of Chromatography A, Volume 1218(34), pp. 57655773

Klein-Marcuschamer, D., Oleskowicz-Popielet, P., Simmons, B.A., Blanch, H.W., 2012. The Challenge of Enzyme Cost in the Production of Lignocellulosic Biofuels. Biotechnology and Bioengineering, Volume 109(4), pp. 1083-1087

Koroch, A., 2007. Quality Atribut of Ginger and Cinamon from Madagascar. ASHS Press

Lauruengtana, V., Paramita, V., Neoh, T.L., Furuta, T., Yoshii, H., 2009. Microencapsulation of Enzymes by Spray Dyring. Japan Journal of Food Engineering, Volume 10(2), pp 79-85

Li, F., Zhang, P., Zhang, G., Tang, X., Wang, S., Jin, S., 2017. Enhancement of Corn Stover Hydrolysis with Rumen Fluid Pretreatment at Different Solid Contents: Effect, Structural Changes and Enzymes Participation. International Biodeterioration \& Biodegradation, Volume 119, pp. 405-412

Mariano, R.G.dB., Couri, S., Freitas, S.P., 2009. Enzymatic Technology to Improve Oil Extraction from Caryocar Brasiliense Camb (Pequi) Pulp. Revista Brasileira de Fruticultura, Volume 31(3), pp. 637-643

Martinez-Avilla, C.G., Sousa-Gallagher, M., Montanez-Saenz, J.C., Rodriguez-Herrera, R., Conteras-Esquivel, J.C., Anguilar, C.N., 2008. Valorization of Mandarin Peels through Enzymatics Pectin Extraction. Valnatura, pp. 21-27

Mesomo, M.C., Corazza, M.L., Ndiaye, P.M., Santa, O.R.D., Cardozo, L., Scheer, A.P., 2013. Supercritical $\mathrm{CO}_{2}$ Extracts and Essential Oil of Ginger (Zingiber officinale R.): Chemical Composition and Antibacterial Activity. The Journal of Supercritical Fluids, Volume 80, pp. 44-49

Nour, A.H., Yap, S.S., Nour, A.H., 2017. Extraction and Chemical Compositions of Ginger (Zingiber Officinale Roscoe) Essential Oils as Cockroaches Repellent. Australian Journal of Basic and Applied Sciences, Volume 11(3), pp. 1-8

Panouile, M., Durant, S., 2007. Enzymatic Extraction of Pectin From Different Plant by Product. INRA

Paramita, V., Yulianto, M.E., Yohana, E., Arifan, F., Hanifah, Amjad, M.T., 2015. Effect of Immobile Isolated Enzymes from Rumen Liquid by using Alginate Matrices on the Bay Leaf Extraction, International Conference of Chemical and Material Engineering(ICCME), Semarang, 2015. America : AIP Conference Proceedings. 
Ptichkina, N.M., Markina, O.A., Rumyantseva, G.N., 2008. Pectin Extraction from Pumkin with the Aid of Microbial Enzymes. Food Hydrocolloids, Volume 22(1), pp 192-195

Rezzouk, S.A., Rezzough, Z.M., Sannier, F., Allaf, K., 2008. A Thermomechanical Preprocessing for Pectin Extraction from Orange Pell. Optimisation by Response Surface Methodology. International Journal of Food Engineering, Volume 4(1), pp.Art10

Rosenthal, A., Pyle, D.L., Niranjan K., 1996. Aqueous and Enzymatic Processes for Edible Oil Extraction. Enzyme and Microbial Technology, Volume 19(6), pp. 402-420

Selinger, L.B., Forsberg, C.W., Cheng, K.J., 1996. The Rumen: A Unique Source of Enzymes for Enhancing Livestock Production. Anaerobe, Volume 2(5), pp. 263-284

Venkatesh, M.S., Raghavan, G.S.V., 2004. An Overview of Microwave Processing and Dielectric Properties of Agri-food Materials. Biosystems Engineering, Volume 88(1), pp. 1-18 